\section{The language of space}

from Angela Croome

L.t.-Colonel Alexeit Leonov, commander designate of the Soyuz crew for next summer's Apollo-Soyuz linkup (the ASTP) announced a nice compromise on the question of space communications during the joint presentation on ASTP progress at the Amsterdam International Astronautical Congress. Last year it was not known what the language of space would be, said Leonov; it had now been decided that on the mission the Russians would speak English and the Americans Russian. In an emergency each team would revert to its own language. It had not however been fixed who would take overall command in a crisis.

The 'book' of operational proce- dures had been written and practised in the four joint training sessions. Emergency procedures had yet to be worked out and there was further polishing of the language to be done; this had proved much more of a problem than originally envisaged (though judging from Leonov's competent performance, his English was no longer a headache). Still to be fully sorted out was the ticklish question of the interrelation of the two control centres. There seemed no clear indication that an American team of controllers would be sitting in at Baikonur next July.

Both the Russians and the Americans assured questioners that there was nothing to choose between the two sides in terms of input to the engineering and other design and operational concepts. Nonetheless behind the scenes American space planners were saying the flow of information was all one way and in the space medicine field in particular there was a great scarcity of adequate Soviet data. How had the Soviet programme eradicated early problems with motion sickness? Skylab astronauts, groggy and sick during their first week in the orbital workshop, would dearly like to know.

\section{Medallurgy}

We are agog to see whether our hint (Nature, 246, 113; 1973) that the Royal Society's policy for the distribution of medals was just a trifle inward-looking has fallen on fertile ground. It's medalstime again next week and several Fellows have told us they will try and persuade Council to look further afield this year.

\title{
correspondence
}

\section{Radioactivity salted away}

SIR-Referring to the article "Fruits of a Faustian bangain" (Nature, 251, $274 ; 1974)$ it appears that the United States propose tests in 1980 for the storing of radioactive waste so as to stop dumping it- - as do the UK, USSR and other nations-in the ocean. The German authorities seem to be ahead of them, as for several years now, low and moderately radioactive waste has been stored in a salt mine close to Hannover by the Gesellschaft für Strahlen-und Umweltforschung owned by the Federal German Republic. And there is still space for thousands of barrels for decades to come. It may be taken for granted that no earthquake will occur to wreak havoc-for millions of years none has happened there, so the only thing to fear is mankind itself by trying to prove its efficiency by discovering a ncw and final way of self destruction.

\section{Hans K. Koenber \\ Laser \& Electro-optik, \\ D-8000 München}

\section{Plasmid moratorium}

SiR-The appeal by a committee of eminent biomedical scientists for a voluntary moratorium on an area of scientific research which may create unpredictable hazards to human health (Nature, 250, 175; 1974) reminded me of a talk which Leo Szilard gave at a writers' club in Moscow in Decomber 1960 which I attended, and where to my knowledge the question of a moratorium was raised for the first time. This story was later told by Szilard and published ${ }^{1}$.

"A year ago last December I was in Moscow to attend the sixth Pugwash conference. And while I was there I was invited to talk to a writers' club about molecular biology, about my work. One of these writers said, 'Now what practical consequences does this have?' So I said, 'As far as I can see it has no practical utility whatever - but of course if you had asked me that about nuclear physics in the 1930s I would have told you the same thing.' And then the Russian said, 'Well in that case, wouldn't it be better if you stopped right now?'".

Yours faithfully, Gertrud Weiss Szilard

La Jolla,

California 92037

Thinking Ahead with Leo Szilard, in Int. Sci. Tech., 33-38 (1962).

\section{Sitting Bull?}

SiR-I was startled to read (Nature, 251, xviii; 1974) that Colorado State University is encouraging "ethnic minorities and women" to apply for the position of Chairperson in its Statistics Department. I reject as highly improbable the implicit assumption that ethnic minorities necessarily consist entirely of males. Nevertheless, I wonder whether the aim is to encourage collective applications nesulting in large-scale migrations of American Indians (that is deviations from their normal distribution). Does this mean that sophisticated statistical tests (excluding Student's $t$, of course) will then be used to select individual chairpeople from large samples? And, even if this analysis is at variance with the real object of the exercise, won't the unsuccessful applicants sioux? Yours faithfully, F. A. SмIтH

Department of Botany,

University of Adelaide,

Adelaide, South Australia 5001

\section{ILLL reactor?}

SIR,-Although apposite and allusive alliterations are always amusing and appropriate as acronyms, Institut Laue-Langevin still satisfies many of us. It recalls that the construction of this long awaited reactor is owed to a Franco-German agreement, whilst with 1,000 visitors and 300 completed experiments in the last year, the Institut is already known as ILL the world over.

I believe we should 'let ILL alone'. Yours faithfully,

Institut Laue-Langevin, W. M. LOMER

\section{Grenoble, France}

\section{Erratum}

SIR In my news note (Nature, August 9) credit for the fallopian tube transplant experiments in animals should have gone to Dr B. M. Cohen of the University of Cape Town Medical School, not to his close colleague $\mathrm{Dr}$ M. Katz, who has drawn my attention to the error. I apologise to both gentlemen.

IAN RIDPATH

35 Oakwood Gardens,

Ilford, Essex 